\title{
Role of Erythrosine in the Inhibition of Adhesion of Lactobacillus fermentum Strain 737 to Mouse Stomach Tissue
}

\author{
By PATRICIA L. CONWAY ${ }^{1 *}$ AND REGINALD F. ADAMS ${ }^{2}$ \\ ${ }^{1}$ University of Göteborg, Department of Marine Microbiology, Carl Skottsbergs Gata 22, \\ S-413 19 Göteborg, Sweden \\ ${ }^{2}$ Division of Food Research, Commonwealth Scientific and Industrial Research Organization, \\ North Ryde 2113, New South Wales, Australia
}

(Received 23 May 1988; revised 27 September 1988; accepted 26 October 1988)

\begin{abstract}
The mechanism by which the food colour erythrosine inhibits the adhesion of Lactobacillus sp. to squamous epithelium in the mouse stomach was investigated using an in vitro adhesion assay. Inhibition of adhesion occurred only after growth of $L$. fermentum in erythrosine which bound to the bacterial cell surface. Erythrosine did not interfere with the receptor on the epithelial cell surface. Growth, but not the ATP content per cell, was affected by the presence of erythrosine in the growth medium. No consistent correlation between hydrophobicity and growth in two different broths was noted when erythrosine was present. Analyses of phenol/water extracts and transmission electron micrographs revealed no reduction in extracellular polysaccharide after growth in the presence of erythrosine. It was concluded that erythrosine affects bacterial metabolism thereby preventing production of the bacterial adhesin which is not the extracellular polysaccharide.
\end{abstract}

\section{INTRODUCTION}

Lactobacillus spp. adhere to and colonize the surface of the squamous epithelia of the digestive tract in rodents (Brownlee \& Moss, 1961), pigs (Dubos et al., 1965), and chickens (Fuller \& Turvey, 1971). This adhesion is host specific (Fuller, 1973; Suegara et al., 1975; Lin \& Savage, 1984) and reported to be mediated by a bacterial extracellular polysaccharide (Savage, 1972; Brooker \& Fuller, 1975; Barrow et al., 1980). In rodents, however, other surface macromolecules have also been proposed as the adhesins (Suegara et al., 1975; Sherman \& Savage, 1986). When the food colour erythrosine was included in the drinking water of rats (Adams \& Conway, 1981), a decrease was observed in the number of lactobacilli adhering to the stomach squamous epithelium. The aim of the work presented here was to determine the site of erythrosine inhibition using an in vitro adhesion assay. In addition, the influence of erythrosine on the growth of bacteria and the production of extracellular polysaccharide was also studied.

\section{METHODS}

Bacterial strains. Lactobacillus fermentum strain FRR B737 (CSIRO Food Research culture collection, NSW, Australia) was freshly isolated from the keratinized squamous epithelium from the stomach of a healthy adult BalbC mouse by enrichment in Rogosa broth (Oxoid) for $24 \mathrm{~h}$ at $37^{\circ} \mathrm{C}$ in an anaerobic jar (Oxoid anaerobe gas generating system). The dominant colony type was purified on Rogosa agar (Oxoid) and identified according to Holdeman et al. (1977). The strain was maintained in a freeze-dried state. For each experiment, an overnight primary culture was grown from a fresh ampoule using liquid medium and growth conditions consistent with that used for each experiment. In addition, freeze-dried cultures of the Lactobacillus fermentum strain FRR B735, which was similarly isolated from rat stomach tissue (Adams \& Conway, 1981), were used.

\footnotetext{
Abbreviations: PB, phosphate buffer; BHI, brain heart infusion; MRS broth, de Man, Rogosa and Sharpe
} Lactobacillus broth; EDAX, energy dispersive analysis X-rays. 
Effect of erythrosine on growth. Erythrosine (2,4,5,7-tetraiodofluorescein, disodium salt) was a food-grade commercial preparation (Edicol Erythrosine, ICI Australia) that conformed with the specifications of FD \& C Red no. 3 (United States of America Code of Federal Regulations, sec. 962; Federal Register 1970, 35, 1910b). It was used without further purification. The growth of L. fermentum strain FRR B737 in Rogosa broth, MRS broth (Oxoid) and Brain Heart Infusion (BHI) broth (Oxoid) was monitored in the presence of 0, 0.05 and 0.1\% erythrosine using $1 \%(\mathrm{v} / \mathrm{v})$ inocula from broth-grown cells. All broths, roll tubes and diluents were prereduced according to Holdeman et al. (1977) using resazurin and cysteine. The broths (100 $\mathrm{ml})$ were sampled frequently during incubation at $37^{\circ} \mathrm{C}$ for up to $30 \mathrm{~h}$ after inoculation. Samples were serially diluted in 10-fóld steps in phosphate-buffered saline (PBS; $0.85 \% \mathrm{NaCl}$ in $0.1 \mathrm{M}$-potassium phosphate buffer, $\mathrm{pH} 7 \cdot 2$ ). Aliquots $(0.1 \mathrm{ml})$ from the serial dilutions were inoculated into roll tubes of MRS agar for enumeration of the colony-forming units (c.f.u.) after $3-5 \mathrm{~d}$ incubation at $37^{\circ} \mathrm{C}$.

In addition, the conductivity of the growth medium during growth of $L$. fermentum strain 737 in prereduced BHI broth in the presence of $0.1 \%$ erythrosine was monitored over $40 \mathrm{~h}$ using a Malthus $8 \mathrm{H} / \mathrm{L} 8$-channel conductance system (Imbros Pty). The ATP levels after $24 \mathrm{~h}$ growth were measured using a Luminometer model 1070 (Lumac) and ATP (Sigma) as the internal standard.

Hydrophobicity. L. fermentum strain 737 was grown in the absence and presence of $0.1 \%$ erythrosine in BHI and MRS broths at $37^{\circ} \mathrm{C}$ for $24 \mathrm{~h}$ in an anaerobic jar using the Oxoid gas generating system. Cultures were centrifuged at $10000 \mathrm{~g}$ for $15 \mathrm{~min}$, washed in $10 \mathrm{ml} 0.01 \mathrm{M}$-Tris $/ \mathrm{HCl}$ buffer, $\mathrm{pH} 7 \cdot 0$, and resuspended in the same buffer to give a concentration of $10^{8}$ bacteria $\mathrm{ml}^{-1}$ as estimated from a standard graph of $\mathrm{OD}_{600}$ plotted against number of viable cells (i.e. c.f.u.). The bacterial suspensions from media without erythrosine were divided into two portions and $0.1 \%$ erythrosine was added to one fraction immediately prior to the hydrophobicity measurement. Hydrophobicity was tested using $1.2 \mathrm{ml}$ of a washed bacterial suspension and $200 \mu \mathrm{l}$ xylene according to Rosenberg et al. (1980) and is expressed as the mean percentage of cells leaving the aqueous phase, as measured by the reduction in the optical density, in five independent assays using different batches of cells. The measurement

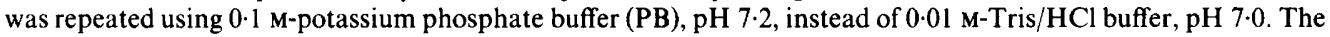
bacterial suspensions were also tested for adhesion to mouse stomach squamous epithelium (see below).

In vitro adhesion assay. BalbC mice (20-25 g) were given free access to a commercial pelletized diet and drinking water supplemented with ampicillin $\left(1 \mathrm{mg} \mathrm{m}^{-1}\right)$ or $0.25 \%$ erythrosine for $4 \mathrm{~d}$ and then killed. A minimum of three mice per adhesion study was used. Portions, each approximately $25 \mathrm{~mm}^{2}$, of the squamous epithelium of the stomach were dissected out and washed three times with $5 \mathrm{ml}$ PBS. In order to avoid centrifuging and washing cells to remove the growth media, because this step could also remove extracellular components, bacteria for the adhesion assay were grown on agar plates. L. fermentum strain 737 was incubated for $18 \mathrm{~h}$ on Rogosa or BHI agar $\pm 0.1 \%$ erythrosine and harvested from the agar surface in $\mathrm{PB}(0 \cdot 1 \mathrm{M}, \mathrm{pH} 7 \cdot 2)$. Bacterial suspensions were adjusted to give approximately $10^{8}$ cells $\mathrm{ml}^{-1}$ as enumerated by direct microscopy.

The tissue pieces were added to suspensions of L. fermentum strain 737 (three pieces per suspension) and incubated at $20^{\circ} \mathrm{C}$ for 30 min with gentle mixing. The tissue pieces were then washed three times in $5 \mathrm{ml}$ PBS and fixed in $3 \%(\mathrm{w} / \mathrm{v})$ glutaraldehyde in PB for examination by scanning electron microscopy (SEM) for quantification of adhering bacteria according to Adams \& Conway (1981). As a control, erythrosine $(0 \cdot 1 \%)$ was also included at the time the tissue pieces and bacterial suspensions were mixed. In addition, tissue and bacterial suspensions were incubated with $0 \cdot 1 \%$ erythrosine in PBS at $5{ }^{\circ} \mathrm{C}$ for $2 \mathrm{~h}$ prior to being used in the in vitro adhesion assay. These erythrosine-treated cells and tissue pieces were washed three times in $5 \mathrm{ml}$ PBS to remove unbound erythrosine.

The in vitro assay was also done using squamous epithelial tissue aseptically removed from the stomachs of male Wistar rats (4-6-weeks-old) fed the same diet and ampicillin as was supplied to the mice. L. fermentum strain 735 , isolated from rat stomach (Adams \& Conway, 1981), was also used. Strain 735 was incubated at $37^{\circ} \mathrm{C}$ in $\mathrm{BHI} \pm$ $0.05 \%$ erythrosine and after $18 \mathrm{~h}$ of anaerobic growth, the tissue pieces were added and the incubation continued under anaerobic conditions for an additional $24 \mathrm{~h}$. The tissue pieces were then washed and prepared for SEM. Control tissue pieces were incubated in sterile BHI broth to ensure that residual indigenous flora after the ampicillin treatment did not interfere with the assay.

Bacterial extracellular polysaccharide. The extracellular polysaccharides on L. fermentum strain 737 grown for $16 \mathrm{~h}$ on Rogosa agar $\pm 0.1 \%$ erythrosine at $37^{\circ} \mathrm{C}$ were extracted using phenol according to Westphal et al. (1952) and assayed according to Dubois et al. (1956) using glucose as the standard. The bacterial cells grown in Rogosa and MRS broth for $16 \mathrm{~h}$ were also prepared for transmission electron microscopy (TEM) for visualization of extracellular material. Samples were fixed overnight in $3 \%(\mathrm{w} / \mathrm{v})$ glutaraldehyde in $0 \cdot 1 \mathrm{M}$-sodium cacodylate buffer, pH 7.0, postfixed in osmium tetroxide and embedded in Epon. Ruthenium red $(0 \cdot 15 \%, \mathrm{w} / \mathrm{v})$ was included in fixation and washing solutions. Sections were poststained with $4 \%(w / v)$ uranyl acetate and lead citrate (Reynolds, 1963) and examined by TEM.

Because of the required poststaining, material visualized by TEM may not have been ruthenium red stained. To confirm that ruthenium red was detectable at the site of Lactobacillus-epithelium interaction, energy dispersive analysis X-rays (EDAX) coupled with SEM were used to confirm the presence of ruthenium on stomach tissue with attached L. fermentum strain 737 from the in vitro assay. Samples from the in vitro assay were prepared for 
SEM as described (Adams \& Conway, 1981), except that $0.15 \%$ ruthenium red was included in the fixing and washing solutions and the samples were vacuum sputter-coated with carbon instead of gold-palladium because of the proximity of palladium and ruthenium in the EDAX detection system.

Location of erythrosine within L. fermentum strain 737. Cells grown in the presence of erythrosine were stained red and the fluorescent character of erythrosine was utilized to determine whether the compound was incorporated within the bacterial cell. An $18 \mathrm{~h}$ culture grown in BHI broth containing $0.1 \%$ erythosine was embedded in paraffin at $60^{\circ} \mathrm{C}$ and cut to yield sections $6-14 \mu \mathrm{m}$ thick. The paraffin was removed by melting at $35^{\circ} \mathrm{C}$ and the sections rinsed with xylene $(10 \mathrm{~min})$ and then stained with cotton blue for $10 \mathrm{~min}$, rinsed with xylene and mounted using the Difco synthetic mounting medium (DPX). The cotton blue solution was prepared the day before use by dissolving $0.05 \mathrm{~g}$ cotton blue in $30 \mathrm{ml}$ lactic acid and the solution was filtered before use $(0.2 \mu \mathrm{m}$ pore size $)$. Sections were examined using fluorescent and conventional light microscopy to determine whether erythrosine could be detected inside the cell or only on the cell wall. As a control for the cotton blue stain, an air-dried smear of the erythrosine-grown cells was stained with cotton blue and rinsed with xylene as for the sections.

For preparation of ethanol precipitates of disrupted cells, a $24 \mathrm{~h}$ culture grown in BHI broth containing $0 \cdot 1 \%$ erythrosine was centrifuged, washed twice in $10 \mathrm{ml}$ PBS and resuspended in $5 \mathrm{ml}$ PBS. The bacterial cells were disrupted by passing the suspension through a French press three times. The resultant sample was centrifuged at $10000 \mathrm{~g}$ for $10 \mathrm{~min}$ and the supernatant precipitated with 3 vols ethanol. The precipitate was harvested by centrifugation and then resuspended in a protease solution $\left(2 \mathrm{mg} \mathrm{m}^{-1}\right.$; Pronase; Calbiochem) in PBS. After incubation at $37^{\circ} \mathrm{C}$ for $30 \mathrm{~min}$, the solution was again precipitated with 3 vols ethanol and the precipitate collected by centrifugation. The first and second ethanol precipitates were examined for the presence of erythrosine (red colour) by direct visual observation.

\section{RESULTS}

\section{Growth in the presence of erythrosine}

While $0 \cdot 1 \%$ erythrosine was not bactericidal to $L$. fermentum strain 737 , the growth of the bacterium was inhibited when grown in BHI, Rogosa or MRS broth containing either $0.05 \%$ or $0.1 \%$ erythrosine. Data for growth in BHI broth $\pm 0.1 \%$ erythrosine are presented in Fig. $1(a)$. The change in conductivity of the medium during growth in BHI broth was studied and a marked difference was detectable when erythrosine was included (Fig. 1 b). Cells grown for $24 \mathrm{~h}$ in prereduced $\mathrm{BHI}$ broth in the absence or presence of $0.1 \%$ erythrosine contained $2.2 \pm 0.3 \mathrm{pg}$ ATP per cell and $4 \cdot 1 \pm 0.4 \mathrm{pg}$ ATP per cell, respectively, each value being the mean \pm SD of four individual assays.

\section{Hydrophobicity measurements}

Bacterial cells grown in the presence of erythrosine were red in colour and remained so even after removal from the growth medium and subsequent washings in buffer. The hydrophobicity decreased significantly $(P<0.05)$ when the bacteria were grown in MRS broth containing $0.1 \%$ erythrosine but not when grown in BHI broth containing $0.1 \%$ erythrosine (Table 1 ). The inclusion of $0.1 \%$ erythrosine in the bacterial suspension immediately prior to the hydrophobicity measurement had no effect on BHI-broth-grown cells but did increase significantly $(P<0.01)$ the hydrophobicity of the MRS grown cells. Growth in both MRS and BHI broth containing erythrosine prevented adhesion, and comparable values to those presented in Table 1 were obtained when PB was used instead of Tris buffer (data not presented).

\section{In vitro adhesion}

The adhesion of L. fermentum strain 737 to mouse stomach epithelium when bacteria and/or tissue pieces were independently exposed to $0.1 \%$ erythrosine is presented in Table 2 . While a slight reduction in adhesion can be noted after short-term exposure of either tissue or bacterial cells to erythrosine, as well as when using tissue from an erythrosine-fed animal, significant inhibition of adhesion $(P<0 \cdot 01)$ was demonstrated only when the bacterial cells were grown in the presence of the erythrosine.

A similar inhibitory effect was observed using the rat-derived L. fermentum strain 735 and rat stomach epithelium. The surface of the control pieces of tissue incubated in sterile BHI broth remained intact and devoid of bacteria after the $24 \mathrm{~h}$ incubation period. The number of bacteria 


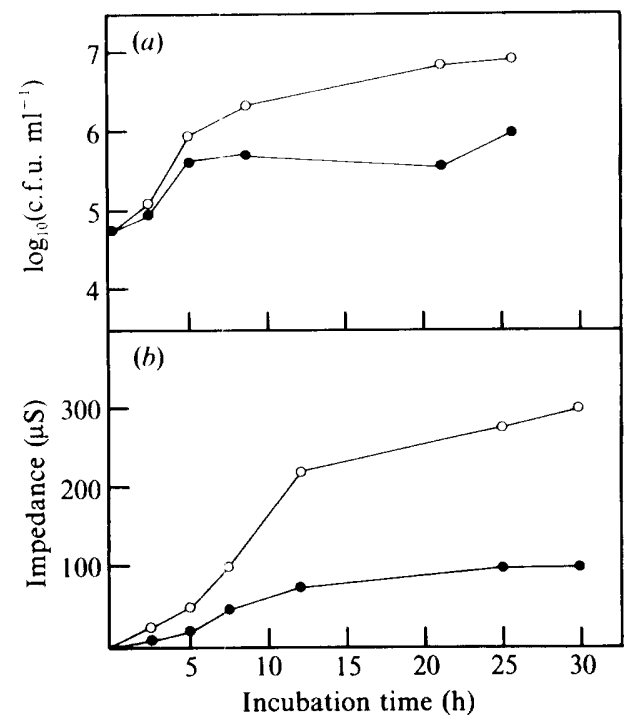

Fig. 1. Anaerobic growth of L. fermentum strain 737 at $37^{\circ} \mathrm{C}$ in BHI broth in the absence $(\mathrm{O})$ or presence $(O)$ of $0.1 \%$ erythrosine. Viable counts $(a)$, expressed as $\log _{10}$ (no. of c.f.u. $\mathrm{ml}^{-1}$ ) and conductivity $(b)$, expressed as the change in impedance of the growth medium, are plotted against time of incubation. Results are typical of four individual experiments.

Table 1. Hydrophobicity and adhesion to squamous epithelium of L. fermentum strain 737 after 24 h growth at $37^{\circ} \mathrm{C}$ in $\mathrm{BHI}$ or MRS broths $\pm 0.1 \%$ erythrosine

Ery, erythrosine.

$\begin{array}{llcl}\begin{array}{l}\text { Growth } \\ \text { medium }\end{array} & \begin{array}{c}\text { Bacterial } \\ \text { suspension* }\end{array} & \text { Hydrophobicity }{ }^{*} & \text { Adhesion } \\ \text { BHI } & 737 & 60 \pm 14 & 4 \cdot 6 \pm 0 \cdot 9^{\mathrm{c}} \\ \text { BHI } & 737+\text { Ery } & 73 \pm 3 & 4 \cdot 7 \pm 1 \cdot 1^{\mathrm{c}} \\ \text { BHI + Ery } & 737 & 77 \pm 4 & 0 \\ \text { MRS } & 737 & 60 \pm 9 & 4 \cdot 2 \pm 0 \cdot 7^{\text {d }} \\ \text { MRS } & 737+\text { Ery } & 83 \pm 4^{\text {a }} & 4 \cdot 2 \pm 1 \cdot 0^{\text {d }} \\ \text { MRS + Ery } & 737 & 25 \pm 5^{\mathrm{b}} & 0\end{array}$

* L. fermentum strain 737 in $0.01 \mathrm{M}-\mathrm{Tris} / \mathrm{HCl}$ buffer $(\mathrm{pH} 7.0) \pm 0.1 \%$ erythrosine as indicated.

$\dagger$ Expressed as the percentage of total bacterial cells removed from the aqueous phase (Rosenberg et al., 1980); mean \pm SD.

$\ddagger$ Expressed as the number of bacteria adhering per $100 \mu \mathrm{m}^{2}$ of squamous epithelium; mean \pm SD of 10 fields of $960 \mu \mathrm{m}^{2}$ per mouse, tissue from three different mice used per test. Results are typical of five individual experiments. Statistical probability was assessed using Student's $t$-test: ${ }^{a} P<0.01$ compared to MRS-737 value; ${ }^{b} P<0.05$ compared to MRS-737 value; ${ }^{C P}<0.01$ compared to BHI + Ery value; ${ }^{d} P<0.01$ compared to MRS + Ery value.

per $100 \mu \mathrm{m}^{2}$ of tissue surface, as enumerated by SEM, was $18.6 \pm 7.0$ (mean \pm SD) when incubated with the bacteria in BHI broth and zero when $0.05 \%$ erythrosine was included in the BHI broth. As strain 735 grew poorly in $0.1 \%$ erythrosine, adhesion was tested for cells grown in $0.05 \%$ erythrosine.

\section{Bacterial extracellular polysaccharide}

The phenol/water extracts of the bacteria grown on Rogosa agar contained 20.9 and $22.7 \mu \mathrm{g}$ glucose per mg dry wt of cells grown in the absence or presence of $0.1 \%$ erythrosine, respectively. There was no correlation between amounts of extractable saccharide and adhesion because 
Table 2. Adhesion of L. fermentum strain 737 to mouse squamous epithelium when bacterial cells or tissue pieces were exposed to $0.1 \%$ erythrosine as indicated

Amp, ampicillin; Ery, erythrosine.

\begin{tabular}{|c|c|c|c|c|}
\hline $\begin{array}{c}\text { Growth } \\
\text { conditions* }\end{array}$ & $\begin{array}{l}\text { Pre-assay } \\
\text { bacterial } \\
\text { treatment }\end{array}$ & $\begin{array}{c}\text { Tissue } \\
\text { source } \dagger\end{array}$ & $\begin{array}{l}\text { Assay } \\
\text { buffer }\end{array}$ & Adhesion $\ddagger$ \\
\hline $\mathrm{BHI}$ & PBS & Amp & PBS & $12 \cdot 6 \pm 3 \cdot 6$ \\
\hline BHI + Ery & PBS & Amp & PBS & $0.1 \pm 0.4$ \\
\hline BHI & PBS & Amp & PBS + Ery§ & $14.8 \pm 4.8$ \\
\hline BHI & PBS & Amp + Ery & PBS & $8 \cdot 1 \pm 2 \cdot 4$ \\
\hline BHI & PBS + Ery§ & Amp + Ery & PBS & $13.4 \pm 3.8$ \\
\hline BHI & PBS & Ery & PBS & $6.5 \pm 2.2$ \\
\hline
\end{tabular}

* Bacteria were grown at $37^{\circ} \mathrm{C}$ for $24 \mathrm{~h}$ on $\mathrm{BHI}$ agar $\pm 0.1 \%$ erythrosine in an anaerobic jar containing an Oxoid anaerobic gas generating system.

+ All tissue pieces were from the stomach squamous epithelium of mice dosed with ampicillin and/or erythrosine. Tissue pieces were held in PBS or PBS + erythrosine as indicated.

$\ddagger$ Adhering bacteria were enumerated by using SEM. Values are the number of bacteria adhering per $100 \mu \mathrm{m}^{2}$ Tissue samples from three different animals were examined; 10 fields of $960 \mu \mathrm{m}^{2}$ per animal were counted. Values are expressed as the mean $\pm \mathrm{SD}$. All values are significant at $P<0.01$ compared to growth in BHI + Ery. Results are typical of three individual experiments.

$\S$ PBS $+0 \cdot 1 \%$ erythrosine for $2 \mathrm{~h}$ at $5{ }^{\circ} \mathrm{C}$.

those grown on Rogosa agar adhered to stomach tissue while those grown on Rogosa agar + $0.1 \%$ erythrosine did not adhere. TEM confirmed that the growth of the bacteria in Rogosa broth containing $0 \cdot 1 \%$ erythrosine had no detectable effect on the extracellular material because layers of 0.036 and $0.038 \mu \mathrm{m}$ thickness were noted around control and erythrosine-grown cells, respectively. The EDAX system confirmed that the acid-polysaccharide stain, ruthenium red, reacted with the bacterial cell because the peak representing elemental ruthenium was detected by EDAX only on stomach tissue with adhering bacteria as visualized by SEM. The stained material visualized by TEM could not be confirmed to contain ruthenium red, hence the use of the EDAX system.

\section{Location of erythrosine within L. fermentum}

Cotton-blue-stained sections of cells of $L$. fermentum strain 737 grown in the presence of erythrosine were examined using conventional and fluorescent light microscopy. Those bacterial cell sections containing erythrosine, as visualized by UV light, were not stained with cotton blue and conversely those bacterial sections which retained the cotton blue stain were not fluorescent. Exposure to cotton blue of air-dried smears of $L$. fermentum strain 737, after growth in the presence of erythrosine, did not result in staining of intact whole cells or cell walls. Thus any material in a section that was stained with cotton blue must have been cytoplasmic. As no material that stained with cotton blue contained erythrosine, it seems that the internal cell constituents were not stained with erythrosine.

The initial ethanol precipitate of the disrupted cells contained erythrosine. After incubation with protease, no erythrosine was detected in the ethanol precipitates, indicating that erythrosine was located in association with protein components of cell-wall fragments.

\section{DISCUSSION}

The red food colour erythrosine was not bactericidal to L. fermentum strain 737 when grown in the two laboratory broths in this study (Fig. 1a). This is consistent with the suggestion from earlier in vivo studies that the Lactobacillus in the rat digestive tract remained viable in the presence of erythrosine (Adams \& Conway, 1981). Although L. fermentum remained viable, bacterial growth (Fig. $1 a$ ) and the conductance of the growth medium (Fig. $1 b$ ) were reduced by erythrosine and as the concentration of erythrosine was increased, so too was the effect on 
bacterial growth. The change in conductance of the medium during growth reflects the metabolism of the bacterial cell because it measures the change in electrical conductivity of the solution as bacterial metabolites are released into solution. The detected reduction of the change in impedance of the culture fluid (Fig. $1 b$ ) for bacterial growth in the presence of erythrosine suggests an alteration in the metabolism of those cells grown in medium containing erythrosine. This inhibitory effect of erythrosine on metabolism did not affect the amount of ATP per cell, a measurement suggested to reflect metabolic activity of aerobic micro-organisms (Gustafsson, 1979). As $L$. fermentum is heterofermentative and the ATP yield for heterofermentative bacteria is only $1 \mathrm{~mol}$ per mol of glucose, changes in metabolic activity may only induce small changes in ATP yield for this organism, and ATP measurements as made here may be too insensitive. Although unsupported by the ATP values, the reduction of growth and conductance of the growth medium support the fact that erythrosine altered the metabolism of the bacterial cells.

No consistent correlation existed between growth in erythrosine and altered hydrophobicity and adhesion for cells grown in BHI or MRS broths. While the short-term exposure of BHIbroth-grown cells to erythrosine did not alter hydrophobicity (Table 1), the observed increase for similarly treated MRS-broth-grown cells may occur because of erythrosine binding to surface components which were located only on the cell surface after growth in MRS broth. An explanation for the observed decreased adhesion for bacteria grown in MRS broth plus erythrosine may be that hydrophobic components on the bacterial cell surface become more easily released from the bacterial surface during the two-phase separation. This could not be confirmed by the commonly used alternative hydrophobicity measurement, hydrophobic interaction chromatography, because the cells were so hydrophobic that they did not pass through a column (data not presented). It is therefore difficult to evaluate the role of hydrophobicity in the adhesion of the L. fermentum strain 737 to the tissue from the results presented.

The in vitro adhesion studies clearly demonstrate that erythrosine plays an active role in preventing or reducing expression of the adhesive capacity of L. fermentum strain 737 to mouse stomach tissue rather than interfering with the receptor on the epithelial surface. This was confirmed for both the mouse and rat system and would explain why the Lactobacillus population was lost from the stomach surface in vivo when animals were given erythrosine in their drinking water for $4 \mathrm{~d}$ (Adams \& Conway, 1981). It is interesting to note that the adhesion of agar-grown cells (Table 2) is greater than that of broth-grown cells (Table 1). This supports the original rationale for using agar-grown cells as growth and/or harvesting from the broth phase appears to reduce the adhesive capacity. This phenomenon has previously been reported for the adhesion of E. coli to mouse small-intestinal epithelium (Zilberberg et al., 1984).

The concentration of ruthenium red (determined by EDAX) on the tissue surface where the Lactobacillus cells were located, and the extracellular material detectable by electron microscopy, is consistent with the findings of others (Brooker \& Fuller, 1975; Barrow et al., 1980) that an extracellular acidic polysaccharide is detectable by microscopy on adhering bacteria. However, a correlation between adhesive capacity and quantitative expression of the ruthenium-stained material was not substantiated by the phenol/water extract analyses for saccharides or by TEM of erythrosine-grown cells. Even though the saccharide analysis of Dubois et al. (1956) may not detect some saccharides, the methodology used for TEM was consistent with that used by Brooker \& Fuller (1975). While the polysaccharide may play an active role in adhesion, from the data presented here it seems that it is not used for the initial phase of attachment, as detected by the in vitro adhesion assay. This fact is supported by other studies: (i) L. fermentum strain 737 devoid of extracellular polysaccharide maintained adhesive characteristics (P. L. Conway, L. Rüdén. T. Nyström and S. Kjelleberg, unpublished results); (ii) Suegara et al. (1975) found no clear correlation between the extracellular polysaccharide and adhesion to rodent stomach tissue; (iii) Savage (1984) suggested that Lactobacillus adhesion to mouse stomach tissue possibly involves several extracellular compounds and Sherman \& Savage (1986) suggested that lipoteichoic acid may be involved.

The role of erythrosine in inhibiting adhesion could not be elucidated from studies of the extracellular polysaccharide or the hydrophobicity of the cell surface. Because erythrosine was 
localized on cell-surface proteins, it may alter the bacterial cell surface and possibly thereby alter the transport of nutrients and metabolites in and out of the cell.

In summary, it is concluded that erythrosine altered the metabolism of L. fermentum strain 737 and thereby prevented the expression or transport of the material responsible for initiating adhesion of the bacterial cells to the stomach tissue surface in vitro. It seems that adhesion was not mediated by either hydrophobic interaction or by the extracellular polysaccharide but rather by another bacterial metabolite. Additional studies suggest that an extracellular protein plays a significant role in adhesion [Conway, 1986; Conway \& Kjelleberg, 1989 (accompanying paper)].

This work was largely performed at the CSIRO Division of Food Research Laboratory, North Ryde, Australia, and some aspects were supported by Chemical Dynamics, Sweden. Lena Töyrä, University of Göteborg. is thanked for her assistance with the transmission electron micrographs.

\section{REFERENCES}

Adams, R. F. \& Conway, P. L. (1981). The effect of erythrosine on the surface-associated bacteria of the rat stomach and caecum. Journal of Applied Bacteriology 51, 171-181.

Barrow, P. A., Brooker, B. E., Fuller, R. \& NEWPORT, M. J. (1980). The attachment of bacteria to the gastric epithelium of the pig and its importance in the microbiology of the intestine. Journal of Applied Bacteriology 48, 147-154.

Brooker, B. E. \& Fuller, R. (1975). Adhesion of lactobacilli to the chicken crop epithelium. Journal of Ultrastructure Research 52, 21-31.

BrownleE, A. \& Moss, W. (1961). The influence of diet on lactobacilli in the stomach of the rat. Journal of Pathology and Bacteriology 82, 513-516.

Conway, P. L. (1986). Protein mediated adhesion of Lactobacillus to mouse stomach tissue (abstract). Microecology Therapy 16, 279-280.

Conway, P. L. \& Kuelleberg, S. (1989). Proteinmediated adhesion of Lactobacillus fermentum strain 737 to mouse stomach squamous epithelium. Journal of General Microbiology 135, 1175-1186.

Dubois, M., Gilles, K. A., Hamilton, J. K., Rebers, P. A. \& SMITH, F. (1956). Colorimetric method for determination of sugars and related substances. Analytical Biochemistry 28, 350-356.

Dubos, R., Schaedler, R. W., Costello, R. \& Hoet, P. (1965). Indigenous, normal and autochthonous flora of the gastrointestinal tract. Journal of Experimental Medicine 122, 67-76.

Fuller, R. (1973). Ecological studies on the lactobacillus flora associated with the crop epithelium of the fowl. Journal of Applied Bacteriology 36, 131-139.

FUller, R. \& TURVEY, A. (1971). Bacteria associated with the intestinal wall of the fowl (Gallus domesticus). Journal of Applied Bacteriology 34, 617-622.

Gustafsson, L. (1979). The ATP pool in relation to the production of glycerol and heat during growth of the halotolerant yeast Debaryomyces hansenii. Archives of Microbiology 120, 15-23.
Holdeman, L. V., Cato, E. P. \& Moore, W. E. C. (1977). Anaerobic Laboratory Manual, 4th edn. Blacksburg, Virginia: Virginia Polytechnic Institute.

Lin, J. H.-C. \& Savage, D. C. (1984). Cryptic plasmids in Lactobacillus strains isolated from the murine gastrointestinal tract. FEMS Microbiological Letters 24. $67-71$

REYNolds, E. S. (1963). The use of lead citrate at high $\mathrm{pH}$ as an electron opaque stain in electron microscopy. Journal of Cell Biology 17, 208-212.

Rosenberg, M., Gutnick, D. \& Rosenberg, E. (1980). Adherence of bacteria to hydrocarbons: a simple method for measuring cell surface hydrophobicity. FEMS Microbiology Letters 9, 29-33.

SAvaGe, D. C. (1972). Association and physiological interaction of indigenous microorganisms and gastrointestinal epithelia. American Journal of Clinical Nutrition 25, 1372-1379.

SavaGe, D. C. (1984). Overview of the association of microbes with epithelial surfaces. Microecology and Therapy 14, 169-182.

Sherman. L. A. \& Savage, D. C. (1986). Lipoteichoic acids in Lactobacillus strains that colonize the mouse gastric epithelium. Applied and Enironmental Microbiology 52, 302-304.

Suegara, N., Morotomi, M., Watanabe, T., Kawai, Y. \& MUTAI, M. (1975). Behaviour of microflora in the rat stomach: adhesion of lactobacilli to the keratinized epithelial cells of the rat stomach in vitro. Infection and Immunity 12, 173-179.

Westphal, V, O.. Luderitz. O. \& Bister, F. (1952). Über die Extraction von Bakterien mit Phenol Wasser. Zeitschrift für Naturforschung 7b, 148-155.

Zilberberg, A., Ofek. I. \& Goldhar, J. (1984). Affinity of adherence in ritro and colonization of mice intestine by enterotoxigenic Escherichia coli (ETA4EC). FEMS Microbiolog! Letters 23. 103-106. 